Journal of Clinical Investigation
Vol. 42, No. 2, 1963

\title{
THE EXPERIMENTAL INDUCTION IN MAN OF SENSITIVITY TO LEUCINE HYPOGLYCEMIA *
}

\author{
By STEFAN S. FAJANS, RALPH F. KNOPF, JOHN C. FLOYD, JR., \\ LAWRENCE POWER, AND JEROME W. CONN
}

(From the Department of Internal Medicine, Division of Endocrinology and Metabolism and the Metabolism Research Unit, The University of Michigan, Ann Arbor, Mich.)

(Submitted for publication August 1, 1962 ; accepted October 24, 1962)

In 1956, Cochrane, Payne, Simpkiss, and Woolf (1) reported that oral administration of L-leucine induces a sharp fall in blood glucose levels in some children with idiopathic familial hypoglycemia, but that it has no effect in normal subjects. Flanagan, Schwartz, and Ryan (2) were the first to report that oral administration of L-leucine to patients with functioning islet-cell tumors also produces a hypoglycemic effect. By the immunoassay of Yalow and Berson for measurement of plasma insulin, an increase has been demonstrated in concentration of plasma insulin during leucine-induced hypoglycemia in infants with idiopathic hypoglycemia $(3-5)$ and in patients with islet-cell tumors $(3,6,7)$.

The studies described below had the following objectives: 1) to see if healthy people could be made sensitive to the hypoglycemic action of leucine, and 2) to study the mechanism by which leucine causes hypoglycemia. The results of this study indicate 1) that sensitivity to leucine hypoglycemia can be induced consistently in healthy subjects after the oral administration of sulfonylurea compounds, and 2) that release of additional insulin is the primary mechanism of action by which leucine causes hypoglycemia in man. ${ }^{1}$

\section{METHODS}

Leucine tests were performed after an overnight fast 1) by the oral administration of $0.2 \mathrm{~g}$ per $\mathrm{kg}$ of an

\footnotetext{
* Presented in part before the 33rd Annual Meeting of the Central Society for Clinical Research, Chicago, November 4 and 5, 1960, and at the Meeting of the American Diabetes Association, New York City, June 24 and 25, 1961; work supported in part by grants AM02244, AM00888, and 2A-5001, National Institute of Arthritis and Metabolic Diseases, U. S. Public Health Service.

1 Preliminary reports of these studies have appeared in abstract form $(8,9)$.
}

aqueous suspension of L-leucine, ${ }^{2}$ or 2 ) by the intravenous infusion of the same dose over a period of $30 \mathrm{~min}$ utes ( $\mathrm{L}$-leucine, $20 \mathrm{mg}$ per $\mathrm{ml}$, dissolved in 0.45 per cent saline). Leucine tests were carried out without pretreatment, and after prior administration of either sulfonylurea drugs or insulin. Control tests were done using oral administration of equimolar amounts of glycine, valine, histidine, or methionine, or else administration of a volume of tap water similar to that of the leucine suspension. Intravenous isotonic saline $(10 \mathrm{ml}$ per $\mathrm{kg}$ body weight) was used to control the intravenous leucine tests. In most of the experiments, blood for glucose determiations was obtained 30 minutes, 15 minutes, 1 minute, and immediately before the start of administration of leucine or of the control material, every 10 minutes during the first hour thereafter, and every 15 to 30 minutes for the next 2 hours.

Tolbutamide response tests were performed by the intravenous administration of $1 \mathrm{~g}$ of sodium tolbutamide dissolved in $20 \mathrm{ml}$ of distilled water. Standard insulin tolerance tests were performed by administration of 0.05 $\mathrm{U}$ of glucagon-free insulin ${ }^{3}$ per $\mathbf{~ k g}$ body weight $\frac{1}{2}$ hour after oral administration of leucine or control material. Leucine tests were also performed during the constant infusion of 4 to $6 \mathrm{U}$ of glucagon-free insulin over 1 to 2 hours. Under these circumstances, the leucine or the control material was given orally or intravenously at the mid-point of the insulin infusions. Glucagon tests were performed by the intravenous administration of $1 \mathrm{mg}$ of crystalline glucagon. ${ }^{3}$

Blood glucose levels were determined by the SomogyiNelson technique (10). During some of the oral and intravenous leucine tests, plasma levels of leucine were estimated by a modification of the technique of Berry (11) and plasma levels of free fatty acids (FFA) by the method of Dole (12). Serum insulin-like activity (ILA) was determined by the method of Renold and co-workers (13) and plasma insulin levels by the immunoassay of Yalow and Berson (3).

Pretreatment with sulfonylurea drugs. Chlorpropamide 4 was administered to healthy subjects for periods

2 Some of the leucine used in these studies was kindly supplied by Dr. Domenic G. Iezzoni, Chas. Pfizer \& Company, Inc., New York, N. Y.

${ }^{3}$ Kindly supplied by Dr. W. R. Kirtley, Lilly Research Laboratories, Indianapolis, Ind.

4 1-Propyl-3-( $p$-chloro-benzenesulfonyl) urea. 
of 2 days to 6 weeks. This compound was used as the sulfonylurea drug in most experiments because of its long half-life of 35 hours (14) and because of the ease with which stable blood sulfonylurea and glucose levels can be attained. It was given in a dosage of $1.0 \mathrm{~g}$ the first day and $0.5 \mathrm{~g}$ thereafter in the majority of experiments. This amount of chlorpropamide produces at most only mild depression of the fasting blood glucose level in healthy subjects. In some of the experiments, decreases of the fasting blood glucose to hypoglycemic levels were achieved by larger maintenance doses, up to $0.875 \mathrm{~g}$ per day.

Before some of the leucine experiments, $1.0 \mathrm{~g}$ of tolbutamide was given orally as a single dose. Before others, this amount was given every 6 hours for up to 24 hours, the last dose of the drug being given 2 hours before administration of leucine.

Pretreatment with insulin. Ultralente insulin (32 to $64 \mathrm{U}$ per day ) was given daily for 2 days to 6 weeks in amounts to produce mild or moderate depression of the fasting blood glucose level.

Constant diets containing at least $300 \mathrm{~g}$ of carbohydrate were consumed by the healthy subjects when repeated leucine and control tests were performed on them during treatment with either chlorpropamide or ultralente insulin.

\section{RESULTS}

Leucine tests in healthy subjects without pretreatment. Figure 1 demonstrates that oral ad-

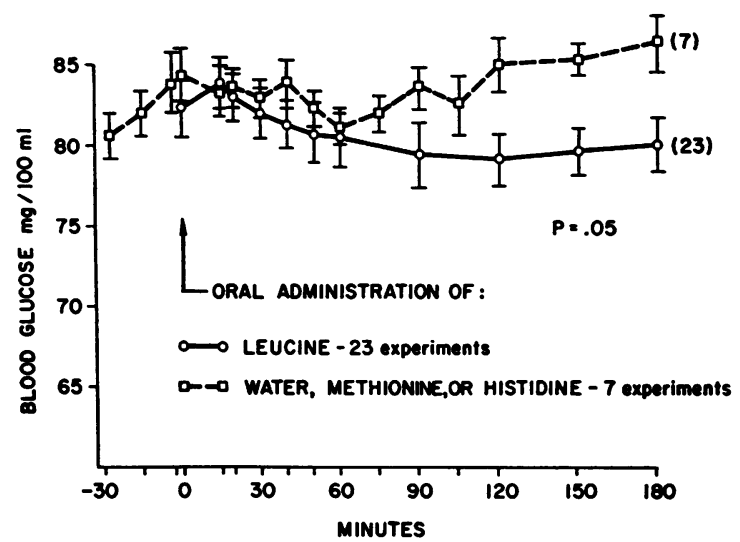

Fig. 1. EFfect of ORALly AdMinistered L-LeUCine UPON BLOOD GLUCOSE OF HEALTHY SUBJECTS.

ministration of leucine to subjects not pretreated with hypoglycemic agents caused only a minor decrease $(3.0 \mathrm{mg}$ per $100 \mathrm{ml})$ of the mean blood glucose levels. Examination of the individual results of the oral leucine tests, however, indicates a significant decline in blood glucose levels of 8 to 14 (mean 10) $\mathrm{mg}$ per $100 \mathrm{ml}$ in 8 of 23 tests. A decrease of $5 \mathrm{mg}$ per $100 \mathrm{ml}$ or less in a single blood sample during the test was not considered significant. Only during 1 of the 7 control tests

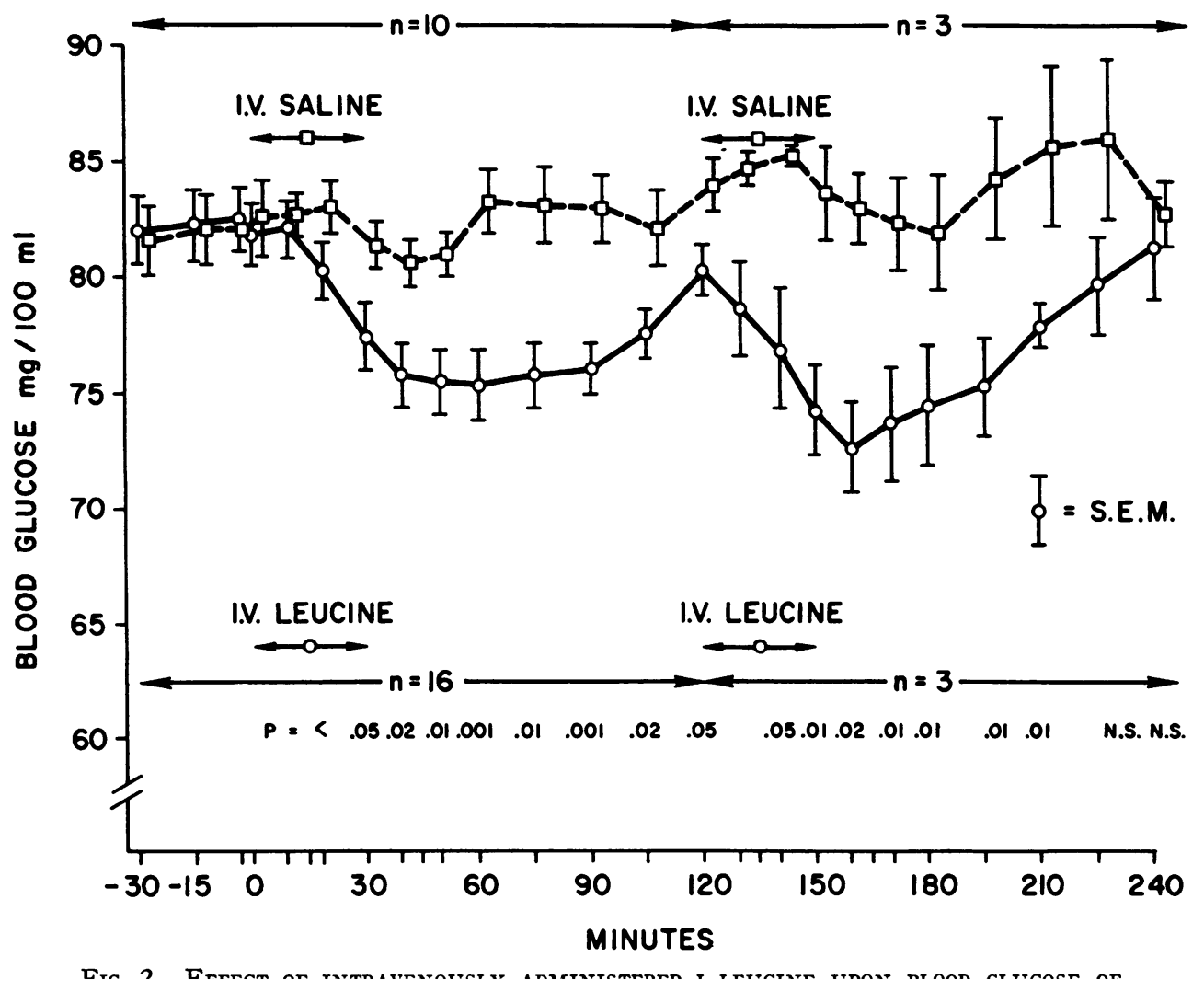


FAJANS, KNOPF, FLOYD, POWER, AND CONN

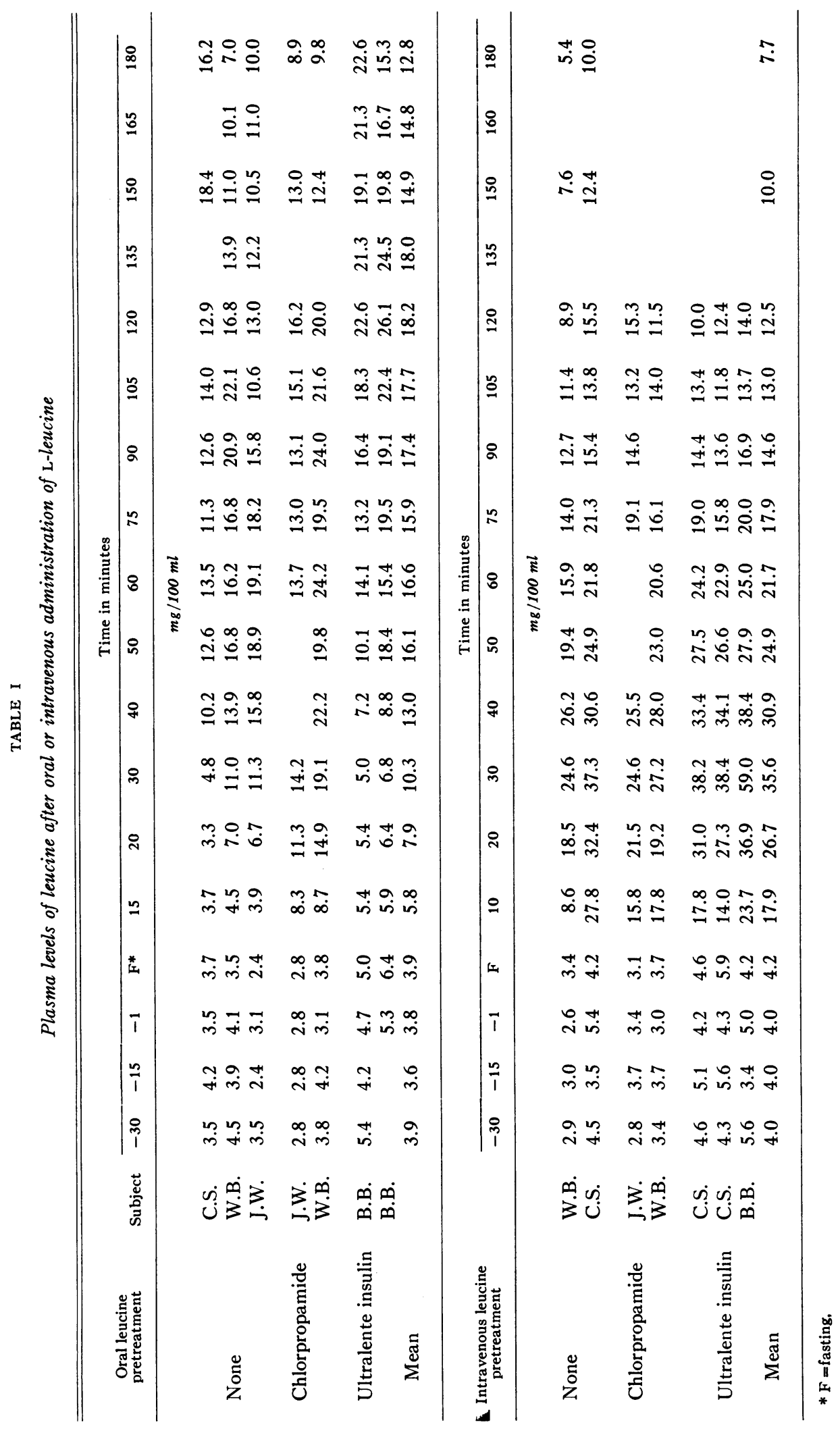


TABLE II

Plasma levels of FFA after administration of L-leucine in healthy subjects

\begin{tabular}{|c|c|c|c|c|c|c|c|c|c|c|c|}
\hline \multirow[b]{2}{*}{ Subject } & \multirow[b]{2}{*}{ Pretreatment } & \multirow{2}{*}{$\begin{array}{l}\text { Administration } \\
\text { of leucine } \\
\text { or control }\end{array}$} & \multicolumn{9}{|c|}{ Time in hours } \\
\hline & & & $-\frac{1}{2}$ & $-\frac{1}{6}$ & F & $\frac{1}{2}$ & 1 & $1 \frac{1}{2}$ & 2 & $2 \frac{1}{2}$ & 3 \\
\hline & & & \multicolumn{9}{|c|}{$\mu E q / L$} \\
\hline W.B. & $\begin{array}{l}\text { None } \\
\text { None }\end{array}$ & $\begin{array}{l}\text { i.v. leucine } \\
\text { i.v. saline }\end{array}$ & $\begin{array}{l}936 \\
857\end{array}$ & $\begin{array}{r}1010 \\
919\end{array}$ & $\begin{array}{r}1123 \\
857\end{array}$ & $\begin{array}{l}898 \\
633\end{array}$ & $\begin{array}{r}674 \\
1000\end{array}$ & $\begin{array}{l}599 \\
960\end{array}$ & $\begin{array}{l}599 \\
960\end{array}$ & 960 & $\begin{array}{l}674 \\
960\end{array}$ \\
\hline D.M. & $\begin{array}{l}\text { None } \\
\text { None } \\
\text { None } \\
\text { None }\end{array}$ & $\begin{array}{l}\text { i.v. leucine } \\
\text { i.v. control } \\
\text { Oral leucine } \\
\text { Oral control }\end{array}$ & $\begin{array}{l}765 \\
510 \\
735 \\
300\end{array}$ & $\begin{array}{l}728 \\
801 \\
890 \\
400\end{array}$ & $\begin{array}{l}801 \\
761 \\
909 \\
520\end{array}$ & $\begin{array}{l}619 \\
681 \\
812 \\
440\end{array}$ & $\begin{array}{l}510 \\
901 \\
677 \\
540\end{array}$ & $\begin{array}{l}510 \\
801 \\
540\end{array}$ & $\begin{array}{l}473 \\
681 \\
503 \\
500\end{array}$ & $\begin{array}{l}401 \\
560 \\
425 \\
460\end{array}$ & $\begin{array}{l}437 \\
425 \\
400\end{array}$ \\
\hline W.B. & $\begin{array}{l}\text { Chlorpropamide } \\
\text { Chlorpropamide } \\
\text { Chlorpropamide } \\
\text { Chlorpropamide }\end{array}$ & $\begin{array}{l}\text { i.v. leucine } \\
\text { i.v. saline } \\
\text { Oral leucine } \\
\text { Oral control }\end{array}$ & $\begin{array}{l}619 \\
520 \\
619 \\
654\end{array}$ & $\begin{array}{l}619 \\
640 \\
656 \\
731\end{array}$ & $\begin{array}{l}581 \\
681 \\
731 \\
712\end{array}$ & $\begin{array}{l}412 \\
781 \\
694 \\
788\end{array}$ & $\begin{array}{l}431 \\
880 \\
412 \\
808\end{array}$ & $\begin{array}{l}560 \\
581 \\
712\end{array}$ & $\begin{array}{l}469 \\
640 \\
638 \\
750\end{array}$ & $\begin{array}{l}619 \\
750\end{array}$ & $\begin{array}{l}431 \\
692\end{array}$ \\
\hline D.M. & $\begin{array}{l}\text { Chlorpropamide } \\
\text { Chlorpropamide } \\
\text { Chlorpropamide } \\
\text { Chlorpropamide }\end{array}$ & $\begin{array}{l}\text { i.v. leucine } \\
\text { i.v. saline } \\
\text { Oral leucine } \\
\text { Oral control }\end{array}$ & $\begin{array}{l}569 \\
569 \\
569 \\
759\end{array}$ & $\begin{array}{l}587 \\
880 \\
690\end{array}$ & $\begin{array}{l}621 \\
483 \\
828 \\
794\end{array}$ & $\begin{array}{l}414 \\
500 \\
587 \\
794\end{array}$ & $\begin{array}{l}276 \\
621 \\
483 \\
725\end{array}$ & $\begin{array}{l}380 \\
640 \\
518 \\
725\end{array}$ & $\begin{array}{l}345 \\
587 \\
690 \\
656\end{array}$ & $\begin{array}{l}449 \\
656 \\
552\end{array}$ & $\begin{array}{l}138 \\
638 \\
735\end{array}$ \\
\hline
\end{tabular}

was there a significant fall in blood glucose levels.

On the other hand, intravenous administration of L-leucine 16 times to eight healthy subjects produced a more significant lowering of the mean blood glucose levels ( $7 \mathrm{mg}$ per $100 \mathrm{ml}$ ), as demonstrated in Figure 2. Maximal decreases in blood glucose levels ranged from 7 to $20 \mathrm{mg}$ per $100 \mathrm{ml}$ with a mean of $10 \mathrm{mg}$ per $100 \mathrm{ml}$. In only 4 of the 16 experiments was there no significant decline in blood glucose levels. During 10 controls tests, using the large infusions of saline, there were minor but not significant decreases of blood glucose levels. To ascertain the consistency of the blood glucose-lowering effect of intravenously administered leucine in the same subject, several tests were performed in three individuals. In one subject, intravenous leucine produced a fall in blood glucose levels once, but not 3 other times; in a second subject, there were 3 positive responses; and in the third, there was 1 positive and 1 negative response. In three subjects, a significant fall in blood glucose during the first infusion was followed by a similar fall in glucose levels during a second infusion 2 hours later (Figure 2).

Plasma levels of leucine reached higher levels after its intravenous than after its oral administration (Table I). After oral administration of the amino acid, decreases in blood glucose occurred when leucine levels were at 12.6, 16.8, and 19.1 mg per $100 \mathrm{ml}$, respectively. In the subjects re- ceiving leucine intravenously, the first decrease in blood glucose occurred when the levels of plasma leucine were 24.6 and $32.4 \mathrm{mg}$ per $100 \mathrm{ml}$.

In two subjects in whom administration of leucine produced a lowering of the blood glucose levels, plasma FFA also decreased (Table II).

Leucine tests in healthy subjects after pretreatment with sulfonylurea drugs. After administration of chlorpropamide to 25 healthy subjects for 2 or more days, oral administration of leucine produced a significant hypoglycemic response consistently in all of 38 experiments. The mean of the maximal decreases in blood glucose levels was $29 \mathrm{mg}$ per $100 \mathrm{ml}$. Table III shows the essential data pertaining to these experiments. In 18 control tests performed with oral administration of glycine, valine, or water after pretreatment of the same subjects with chlorpropamide, no decreases in blood glucose levels were observed.

Figures 3 and 4 show typical examples of leucine-induced hypoglycemia after pretreatment of healthy subjects with chlorpropamide. Figure 4 also indicates that leucine hypoglycemia was preceded by and associated with rising plasma insulin levels.

In three subjects, oral leucine tests were performed after pretreatment with chlorpropamide for 1 and 3 days. The maximal decreases in blood glucose levels produced by leucine after 1 day of chlorpropamide administration were 18,10 , and $11 \mathrm{mg}$ per $100 \mathrm{ml}$, respectively. After 3 days of 
TABLE III

Comparison of leucine-induced hypoglycemia in healthy subjects during administration of chlorpropamide and ultralente insulin

\begin{tabular}{|c|c|c|c|c|c|c|c|c|c|c|c|}
\hline Subject & $\begin{array}{l}\text { Chlor- } \\
\text { prop- } \\
\text { amide }\end{array}$ & Dosage & $\begin{array}{c}\text { Fasting } \\
\text { blood } \\
\text { glucose }\end{array}$ & $\begin{array}{l}\text { Lowest } \\
\text { blood } \\
\text { glucose }\end{array}$ & $\begin{array}{l}\text { Onset of } \\
\text { hypogly- } \\
\text { cemia }\end{array}$ & Subject & $\begin{array}{l}\text { Ultra- } \\
\text { lente } \\
\text { insulin }\end{array}$ & Dosage & $\begin{array}{c}\text { Fasting } \\
\text { blood } \\
\text { glucose }\end{array}$ & $\begin{array}{c}\text { Lowest } \\
\text { blood } \\
\text { glucose }\end{array}$ & $\begin{array}{l}\text { Onset of } \\
\text { hypogly- } \\
\text { cemia }\end{array}$ \\
\hline & days & $g$ & \multicolumn{2}{|c|}{$m g / 100 m l$} & $\min$ & & days & $U$ & \multicolumn{2}{|c|}{$\mathrm{mg} / 100 \mathrm{ml}$} & $\min$ \\
\hline \multirow[t]{5}{*}{ D.M. } & 3 & 0.5 & 77 & 56 & 20 & D.M. & 3 & 36 & 66 & 61 & 50 \\
\hline & 2 & 0.5 & 85 & 53 & 40 & & 6 & 38 & 72 & 56 & 90 \\
\hline & 3 & 0.5 & 78 & 51 & 50 & & 19 & 36 & 67 & 72 & \\
\hline & 10 & 0.5 & 66 & 30 & 30 & & 21 & 36 & 70 & 56 & 60 \\
\hline & 13 & 0.5 & 70 & 38 & 20 & & $\begin{array}{l}29 \\
32\end{array}$ & $\begin{array}{l}36 \\
37\end{array}$ & $\begin{array}{l}80 \\
59\end{array}$ & $\begin{array}{l}80 \\
54\end{array}$ & 90 \\
\hline \multirow[t]{3}{*}{ M.S. } & 3 & 0.875 & 83 & 48 & 30 & M.S. & 3 & 43 & 85 & 73 & 30 \\
\hline & 4 & 1.0 & 57 & 42 & 15 & & 4 & 40 & 74 & 61 & 60 \\
\hline & & & & & & & 5 & 42 & 52 & 46 & 90 \\
\hline M.F. & 3 & 0.5 & 73 & 52 & 30 & M.F. & 4 & 34 & 57 & 50 & 50 \\
\hline W.K. & 3 & 0.75 & 52 & 40 & 50 & W.K. & 3 & 43 & 62 & 57 & 60 \\
\hline F.S. & 3 & 1.0 & 76 & 40 & 20 & F.S. & 3 & 55 & 87 & 80 & 90 \\
\hline R.R. & 3 & 1.0 & 59 & 46 & 30 & & & & & & \\
\hline \multirow[t]{2}{*}{ R.H. } & 4 & 0.5 & 74 & 36 & 20 & R.H. & 4 & 38 & 73 & 73 & \\
\hline & & & & & & & 4 & 38 & 81 & 76 & \\
\hline \multirow[t]{2}{*}{ J.S. } & 4 & 0.75 & 63 & 24 & 15 & J.S. & 7 & 56 & 88 & 82 & 50 \\
\hline & & & & & & & 9 & 64 & 59 & 41 & 40 \\
\hline B.F. & 2 & 0.75 & 66 & 32 & 40 & D.C. & 3 & 55 & 72 & 70 & \\
\hline \multirow[t]{2}{*}{ D.L. } & 2 & 0.5 & 70 & 34 & 40 & D.L. & 8 & 30 & 60 & 49 & 120 \\
\hline & 5 & 0.5 & 70 & 47 & 60 & M.N. & 3 & 55 & 64 & 65 & \\
\hline \multirow[t]{3}{*}{ G.S. } & 4 & 0.875 & 57 & 28 & 20 & G.S. & 4 & 45 & 61 & 53 & 90 \\
\hline & 7 & 0.5 & 60 & 32 & 20 & & 6 & 40 & 69 & 71 & \\
\hline & 12 & 0.875 & 63 & 35 & 20 & & & & & & \\
\hline T.K. & 3 & 0.5 & 70 & 45 & 50 & T.K. & 5 & 38 & 69 & 76 & \\
\hline M.A. & 3 & 0.5 & 73 & 39 & 30 & L.S. & 3 & 36 & 71 & 80 & \\
\hline B.C. & 3 & 0.5 & 72 & 33 & 15 & B.C. & 4 & 34 & 66 & 66 & \\
\hline \multirow[t]{2}{*}{ A.C. } & 3 & 0.25 & 86 & 52 & 30 & A.C. & 3 & 32 & 72 & 62 & 15 \\
\hline & 3 & 0.25 & 80 & 34 & 30 & & & & & & \\
\hline D.R. & 3 & 0.5 & 90 & 61 & 15 & D.R. & 2 & 44 & 68 & 58 & 50 \\
\hline J.W. & 3 & 0.5 & 78 & 63 & 15 & D.M. & 4 & 60 & 76 & 78 & \\
\hline \multirow[t]{3}{*}{ R.M. } & 3 & 0.5 & 84 & 49 & 30 & R.M. & 3 & 40 & 75 & 77 & \\
\hline & 10 & 0.5 & 75 & 52 & 30 & & 5 & 44 & 65 & 56 & 150 \\
\hline & & & & & & & 9 & 44 & 67 & 55 & 60 \\
\hline \multirow[t]{5}{*}{ J.H. } & 6 & 0.5 & 63 & 31 & 15 & & 13 & 44 & 66 & 55 & 40 \\
\hline & & & & & & & 16 & 46 & 51 & 32 & 40 \\
\hline & & & & & & & 20 & 47 & 73 & 65 & 50 \\
\hline & & & & & & & 31 & 42 & 78 & 74 & \\
\hline & & & & & & & 38 & 46 & 69 & 69 & \\
\hline \multirow{2}{*}{ R.D. } & 3 & 0.5 & 68 & 43 & 20 & R.D. & 4 & 36 & 66 & 63 & \\
\hline & & & & & & & 4 & 30 & 48 & 46 & \\
\hline \multirow[t]{4}{*}{ J.S. } & 3 & 0.5 & 77 & 58 & 40 & J.S. & 6 & 38 & 76 & 72 & \\
\hline & 9 & 0.5 & 71 & 38 & 40 & & 21 & 36 & 69 & 67 & \\
\hline & 3 & 0.5 & 74 & 52 & 40 & & 25 & 37 & 67 & 59 & 120 \\
\hline & 13 & 0.5 & 66 & 35 & 20 & & & & & & \\
\hline \multirow[t]{3}{*}{ B.B. } & 4 & 0.5 & 71 & 48 & 50 & B.B. & 4 & 33 & 73 & 72 & \\
\hline & & & & & & & 10 & 38 & 60 & 43 & 60 \\
\hline & & & & & & & 15 & 32 & 70 & 66 & \\
\hline C.S. & 7 & 0.5 & 70 & 50 & 40 & c.s. & 5 & 37 & 66 & 51 & 60 \\
\hline & & & & & & & 11 & 34 & 61 & 59 & \\
\hline J.W. & 4 & 0.5 & 76 & 36 & 20 & & 19 & 35 & 78 & 76 & \\
\hline W.B. & 4 & 0.5 & 76 & 28 & 15 & & & & & & \\
\hline & $\mathrm{N}=\mathbf{3 8}$ & & & & & & $\mathrm{N}=46$ & & & & \\
\hline & Mean & & 71.6 & 42.4 & 29.3 & & & & 68.7 & 63.1 & 67.3 \\
\hline 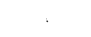 & SE & & \pm 1.4 & \pm 1.62 & \pm 2.98 & & & & \pm 1.29 & \pm 1.76 & \pm 6.48 \\
\hline & & & & & Sum & results & & & & & \\
\hline & Trea & ent & E & $\begin{array}{l}\text { No. of } \\
\text { periments }\end{array}$ & & & & $\begin{array}{l}\text { vest blood } \\
\text { cose after } \\
\text { leucine }\end{array}$ & & $\begin{array}{r}\text { Tim } \\
\text { initia } \\
\text { in blood } \\
\text { after } 1\end{array}$ & $\begin{array}{l}\text { f } \\
\text { rop } \\
\text { ucose } \\
\text { ine }\end{array}$ \\
\hline & & & & & & & $m g$ & $/ 100 \mathrm{ml} *$ & & $m$ & \\
\hline & $\begin{array}{l}\text { Chlorpr } \\
\text { Ultralen } \\
\text { p }\end{array}$ & $\begin{array}{l}\text { mide } \\
\text { insulin }\end{array}$ & & $\begin{array}{l}38 \\
46\end{array}$ & & & & $\begin{array}{l}4 \pm 1.62 \\
1+ \pm 1.76 \\
<0.001\end{array}$ & & $\begin{array}{r}29[1 \\
67[1 \\
<0\end{array}$ & $\begin{array}{l}0] \\
50] \\
1\end{array}$ \\
\hline
\end{tabular}

$*$ Mean \pm SE.

Mean, with range given in brackets.

$\mathrm{p}=\mathbf{0 . 0 5}$. 
A.C., female, AGe 24

CHLORPROPAMIDE
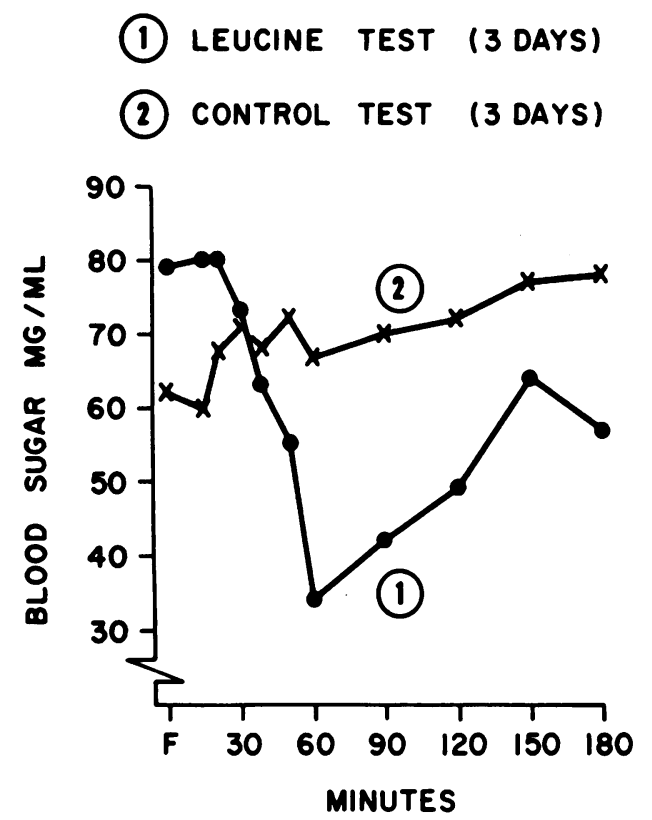

U.L. INSULIN ( 32 UNITS)
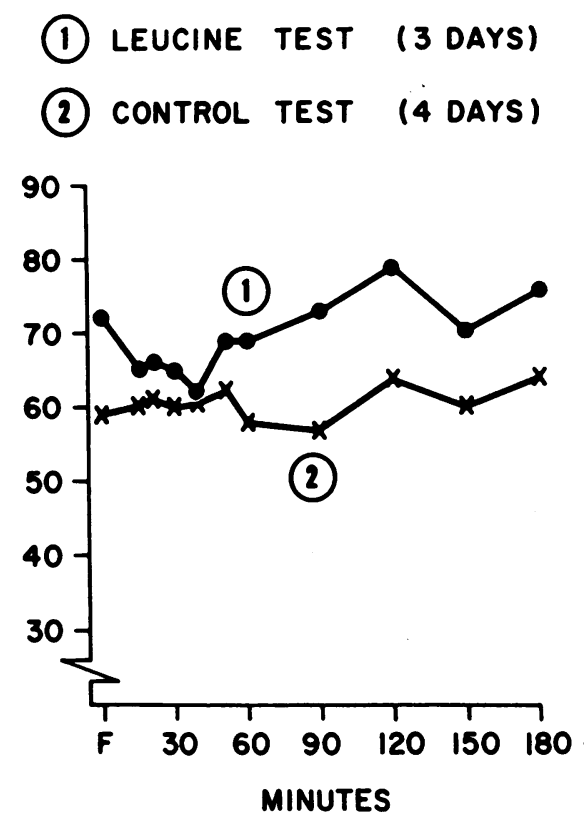

Fig. 3. Effect of orally administered L-LeUcine Upon bloOd Glucose of a healthy SUBJECT PRETREATED EITHER WITH CHLORPROPAMIDE OR ULTRALENTE INSUlin. Number of days of pretreatment given in parentheses.

drug administration, the decreases were 20, 31, and $32 \mathrm{mg}$ per $100 \mathrm{ml}$, respectively.

Leucine hypoglycemia was induced 2 hours after the administration of a single 1-g oral dose of tolbutamide in two of four subjects, with maximal decreases of blood glucose levels of 12 and $23 \mathrm{mg}$ per $100 \mathrm{ml}$. During control tests, a decline in blood glucose did not occur 2 hours after administration of tolbutamide. In the other two subjects, administration of $1.0 \mathrm{~g}$ of tolbutamide both 8 hours as well as 2 hours before the leucine feeding produced sensitivity to leucine hypoglycemia with decreases in blood glucose of 26 and $12 \mathrm{mg}$ per $100 \mathrm{ml}$. These four subjects did not show a decrease in blood glucose levels when leucine was given orally without pretreatment with tolbutamide.

Leucine was administered intravenously 13 times in eight healthy subjects after pretreatment with chlorpropamide (Figure 5). Again, a hypoglycemic effect was obtained consistently in each experiment. The mean of the maximal decreases in blood glucose levels was $38 \mathrm{mg}$ per
$100 \mathrm{ml}$. The first discernible hypoglycemic effect occurred in 10 minutes in ten of the experiments and within 20 minutes in the other three. In six subjects, a second leucine infusion given 2 hours after the beginning of the first infusion again produced significant decreases in blood glucose levels (Figure 5).

In subjects pretreated with chlorpropamide, plasma levels of leucine of 11.3 to $21.5 \mathrm{mg}$ per 100 $\mathrm{ml}$ were sufficient to cause large decreases in blood glucose levels. For instance, in J.W. (Table I) a plasma level of leucine of 11.3 to $14.2 \mathrm{mg}$ per $100 \mathrm{ml}$ caused a decrease in blood glucose of 40 $\mathrm{mg}$ per $100 \mathrm{ml}$.

Table II demonstrates decreases in FFA after administration of leucine to two subjects pretreated with chlorpropamide.

Glucagon was effective in reversing leucineinduced hypoglycemia. In one subject pretreated with chlorpropamide for 13 days $(0.875 \mathrm{~g}$ the day before the test), a fasting blood glucose level of $42 \mathrm{mg}$ per $100 \mathrm{ml}$ had decreased to $31 \mathrm{mg}$ per 100 $\mathrm{ml} 20$ minutes after oral administration of leucine. 
Intravenous administration of glucagon at that time produced a maximal rise in blood glucose to $93 \mathrm{mg}$ per $100 \mathrm{ml}$ in 30 minutes, with a subsequent fall to preglucagon levels by 2 hours after the leucine had been given,

In four subjects, leucine tests and intravenous tolbutamide tests were performed after the subjects had been pretreated with sufficient chlorpropamide to produce definite lowering of the fasting blood glucose level. The hypoglycemic response after oral or intravenous administration of leucine was considerably greater in each case than after intravenous administration of sodium tolbutamide (Table IV).

Leucine tests in healthy subjects during acute administration of insulin. Orally administered leucine did not modify the hypoglycemia produced during intravenous infusion of $6 \mathrm{U}$ of insulin $(0.08$ to $0.1 \mathrm{U}$ per $\mathrm{kg}$ ) in three subjects (Figure 6).
Intravenous leucine tests were performed during insulin infusions ( $4 \mathrm{U}$ or $0.05 \mathrm{U}$ per $\mathrm{kg}$ ) in two other subjects. During the control tests, a sustained hypoglycemic effect of 24 to $26 \mathrm{mg}$ per $100 \mathrm{ml}$ was obtained when insulin was infused in a constant volume of saline over 60 minutes. During a second insulin infusion, leucine was included in the same volume between 30 and 60 minutes of the test. Thirty minutes after the end of the leucine infusion, the blood glucose levels were 13 and $10 \mathrm{mg}$ per $100 \mathrm{ml}$ lower than during the control test without leucine. In these two subjects, leucine produced decreases in blood glucose of 10 and $12 \mathrm{mg}$ per $100 \mathrm{ml}$, respectively, when infused without insulin.

In nine other subjects, leucine did not modify the hypoglycemia produced during standard insulin tolerance test (Table V).

Leucine tests in healthy subjects after pretreatment with ultralente insulin. Oral leucine tests

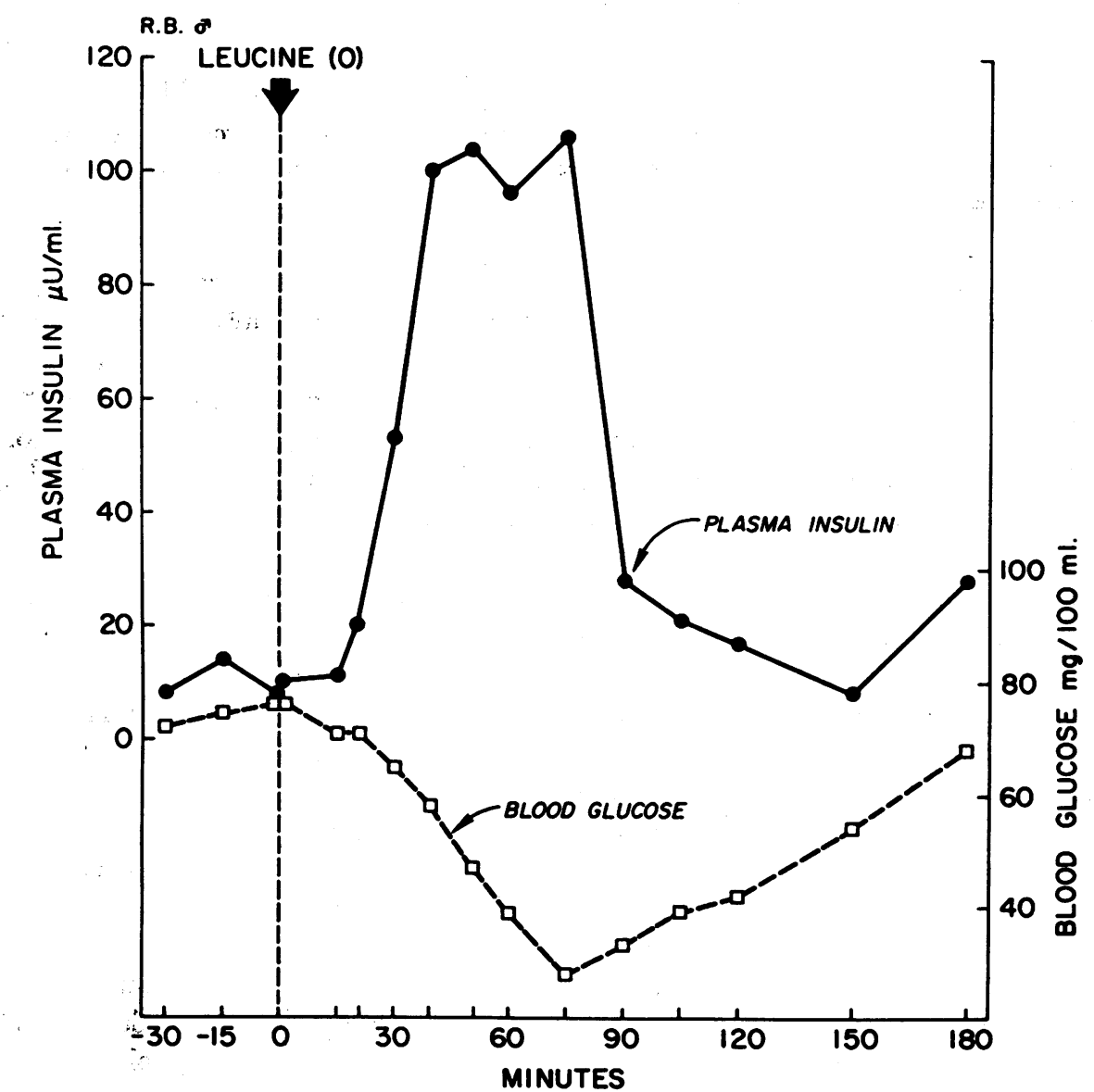

Fig. 4. EFFect of ORALly AdMINISTERED L-LeUCine UPON BLOOD GLUCOSE AND PLASMA INSULIN OF A HEALTHY SUBJECT PRETREATED WITH CHLORPROPAMIDE. 


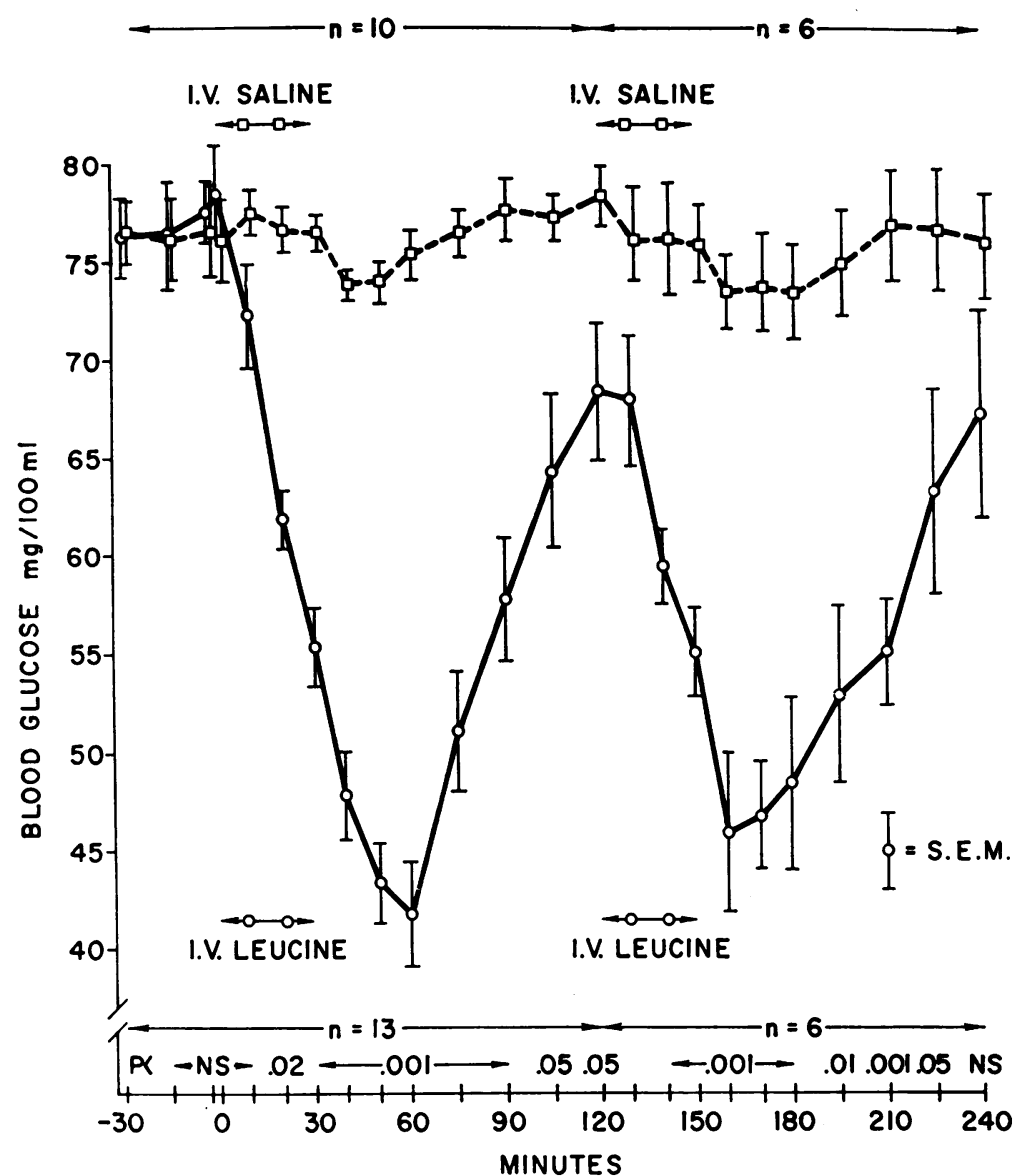

Fig. 5. EFFECT OF INTRAVENOUSLy AdMinistered L-LeUCINE UPON BLOOD GLUCOSE OF HEALTHY SUBJECTS PRETREATED WITH CHLORPROPAMIDE.

TABLE IV

Effect of administration of L-leucine or sodium tolbutamide on blood glucose levels of healthy subjects after pretreatment with chlorpropamide

\begin{tabular}{|c|c|c|c|c|c|c|c|c|c|c|c|c|c|c|}
\hline \multirow[b]{2}{*}{ Subject } & \multirow[b]{2}{*}{ Chlorpropamide } & \multirow[b]{2}{*}{ Test } & \multicolumn{12}{|c|}{ Time in minutes } \\
\hline & & & F & 15 & 20 & 30 & 40 & 45 & 50 & 60 & 90 & 120 & 150 & 180 \\
\hline & days & & & & & & & & & & & & & \\
\hline D.M. & $\begin{array}{l}10 \\
12\end{array}$ & $\begin{array}{l}\text { Leucine (0) } \\
\text { Tolb. } \dagger\end{array}$ & $\begin{array}{l}63 \\
63\end{array}$ & $\begin{array}{l}67 \\
58\end{array}$ & $\begin{array}{l}66 \\
57\end{array}$ & $\begin{array}{l}56 \\
55\end{array}$ & $\begin{array}{l}51 \\
50\end{array}$ & & $\begin{array}{l}42 \\
50\end{array}$ & $\begin{array}{l}38 \\
50\end{array}$ & $\begin{array}{l}30 \\
53\end{array}$ & $\begin{array}{l}30^{*} \\
55\end{array}$ & 61 & 59 \\
\hline J.S. & $\begin{array}{l}12 \\
13\end{array}$ & $\begin{array}{l}\text { Tolb. } \dagger \\
\text { Leucine (0) }\end{array}$ & $\begin{array}{l}67 \\
66\end{array}$ & $\begin{array}{l}54 \\
67\end{array}$ & $\begin{array}{l}53 \\
61\end{array}$ & $\begin{array}{l}51 \\
53\end{array}$ & 47 & 52 & 48 & $\begin{array}{l}55 \\
35\end{array}$ & $\begin{array}{l}60 \\
40^{*}\end{array}$ & 56 & 60 & 59 \\
\hline G.S. & $\begin{array}{r}7 \\
8 \\
12\end{array}$ & $\begin{array}{l}\text { Leucine (0) } \\
\text { Tolb. } \dagger \\
\text { Leucine }(0)\end{array}$ & $\begin{array}{l}59 \\
67 \\
63\end{array}$ & $\begin{array}{l}60 \\
62\end{array}$ & $\begin{array}{l}53 \\
58 \\
57\end{array}$ & $\begin{array}{l}49 \\
58 \\
54\end{array}$ & $\begin{array}{l}40 \\
47\end{array}$ & 54 & $\begin{array}{l}32 \\
39\end{array}$ & $\begin{array}{l}34 \\
56 \\
41\end{array}$ & $\begin{array}{l}39 \\
55 \\
35\end{array}$ & $\begin{array}{l}41 \\
64 \\
39\end{array}$ & $\begin{array}{l}50 \\
63 \\
43\end{array}$ & $\begin{array}{l}55 \\
63 \\
66\end{array}$ \\
\hline D.M. & $\begin{array}{l}20 \\
21\end{array}$ & $\begin{array}{l}\text { Tolb. } \ddagger \\
\text { Leucine (i.v.) }\end{array}$ & $\begin{array}{l}76 \\
71\end{array}$ & $\begin{array}{l}63 \\
61\end{array}$ & $\begin{array}{l}60 \\
55\end{array}$ & $\begin{array}{l}59 \\
49\end{array}$ & $\begin{array}{l}59 \\
40\end{array}$ & & $\begin{array}{l}59 \\
34\end{array}$ & $\begin{array}{l}57 \\
37\end{array}$ & $\begin{array}{l}59 \\
38\end{array}$ & $\begin{array}{l}63 \\
53\end{array}$ & 67 & 66 \\
\hline
\end{tabular}

* Test terminated because of appearance of severe central nervous system symptoms.

† Tolb. $1 \mathrm{~g}$ Na tolbutamide i.v. over 2 minutes after fasting blood glucose.

$\ddagger$ Tolb. $1 \mathrm{~g}$ Na tolbutamide i.v. over 2 minutes after fasting blood glucose $+1 \mathrm{~g}$ i.v. during first 30 minutes in saline. 


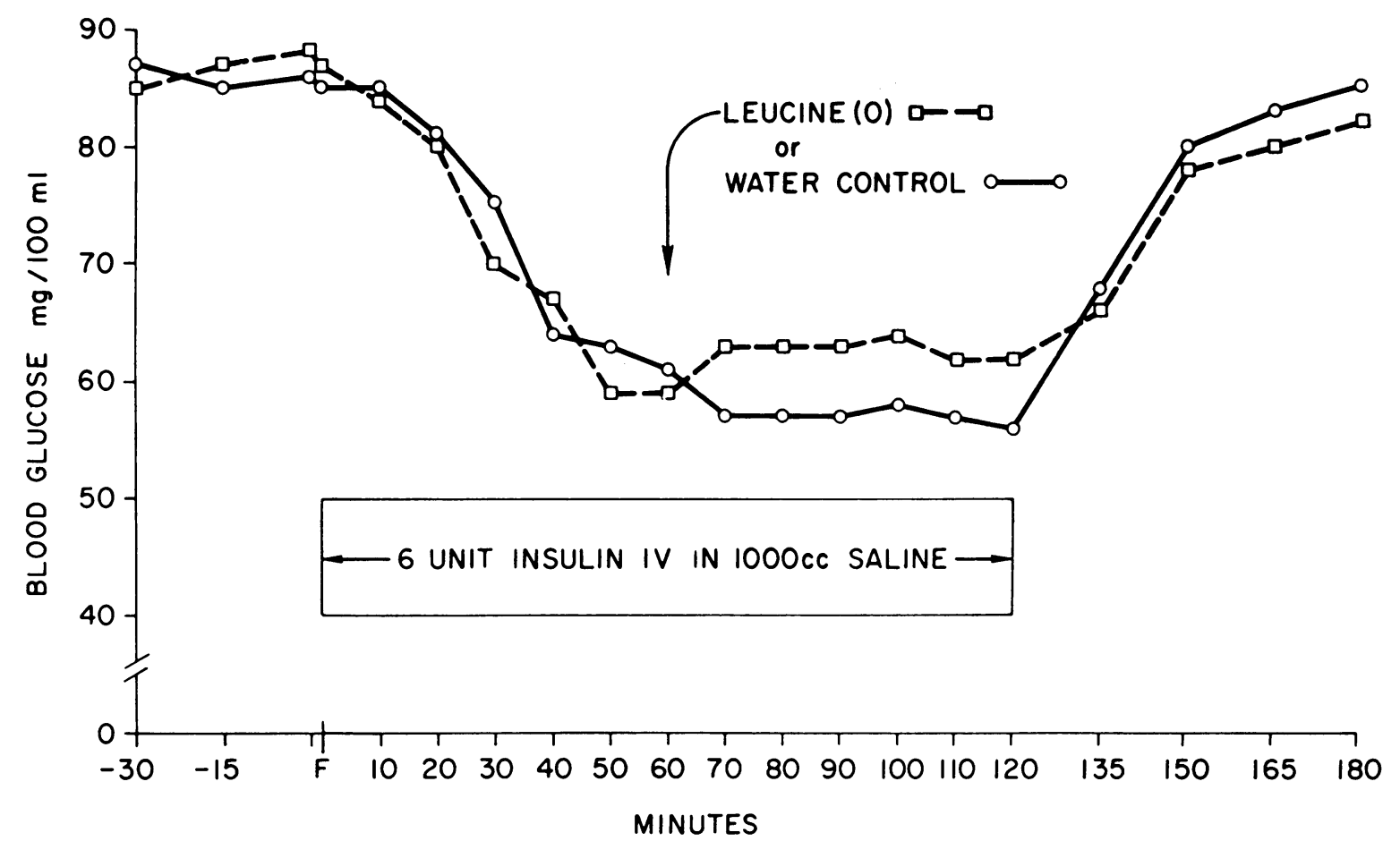

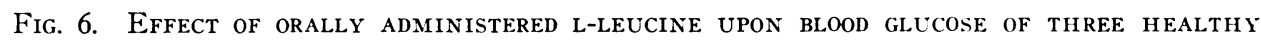
SUBJECTS DURING INFUSIONS OF INSULIN.

were performed 46 times in 22 healthy subjects after pretreatment with ultralente insulin for 2 or more days (Table III). A significant leucineinduced hypoglycemic effect could not be demonstrated consistently and was apparent in only 21 of the 46 experiments. The mean of the maximal decreases in blood glucose levels was only $5.6 \mathrm{mg}$ per $100 \mathrm{ml}$. The mean time of onset of the initial fall in blood glucose after leucine administration occurred at a significantly later time than after chlorpropamide administration. Twenty-one control tests performed during ultralente insulin administration showed no significant change in blood glucose levels 15 times, a rise in blood glucose levels 4 times ( 8 to $30 \mathrm{mg}$ per $100 \mathrm{ml}$ ), and a de- crease of 9 to $13 \mathrm{mg}$ per $100 \mathrm{ml}$ on two occasions. Figure 3 contrasts the effect of leucine administration after treatment with ultralente insulin with that produced after treatment with chlorpropamide in one subject.

Intravenous leucine tests were performed in six subjects pretreated with ultralente insulin. The mean fasting blood glucose level was $61 \mathrm{mg}$ per $100 \mathrm{ml}$ before leucine administration. After administration of leucine, the mean of the maximal decreases in blood glucose was $11 \mathrm{mg}$ per $100 \mathrm{ml}$. This compares with a decrease of $10 \mathrm{mg}$ per 100 $\mathrm{ml}$ when leucine was infused in healthy subjects without pretreatment.

Plasma levels of leucine were determined dur-

TABLE V

Effect of orally administered L-leucine on levels of blood glucose during intravenous insulin tolerance tests*

\begin{tabular}{|c|c|c|c|c|c|c|c|c|c|c|c|c|c|c|c|}
\hline \multirow[b]{2}{*}{ Test } & & \multicolumn{14}{|c|}{ Time in minutes } \\
\hline & & $\mathbf{F}$ & 10 & 15 & 20 & 25 & 30 & 35 & 40 & 45 & 60 & 75 & 90 & 105 & 120 \\
\hline \multirow[t]{2}{*}{ ITT } & Mean $(n=9)$ & 80.3 & 64.4 & 55.0 & 44.9 & 43.4 & 39.2 & 49.7 & 59.8 & 66.8 & 67.4 & 76.0 & 80.2 & 79.5 & 85.9 \\
\hline & SEM & 1.97 & 4.13 & 5.54 & 4.27 & 4.81 & 6.29 & 3.08 & 3.63 & 2.66 & 8.40 & 3.85 & 1.63 & 4.04 & 2.65 \\
\hline Leucine & Mean $(n=12)$ & 77.0 & 64.1 & 53.8 & 45.5 & 37.5 & 45.6 & 51.8 & 59.6 & 63.2 & 72.3 & 73.6 & 75.3 & 75.6 & 79.4 \\
\hline +ITT & SEM & 2.03 & 1.95 & 2.72 & 2.31 & 4.68 & 2.16 & 1.66 & 2.02 & 2.21 & 1.47 & 1.97 & 1.70 & 1.71 & 2.05 \\
\hline
\end{tabular}

* Leucine administered orally $\frac{1}{2}$ hour before i.v. administration of insulin, $0.05 \mathrm{U}$ per $\mathrm{kg} . \quad \mathrm{p}$ is NS. 
ing 5 experiments when leucine was administered to subjects pretreated with ultralente insulin (Table I). Increases in plasma levels of leucine after its oral administration were of the same magnitude as in chlorpropamide-pretreated subjects. In one subject. B.B., no decreases in blood glucose occurred on one occasion and a decrease of only $9 \mathrm{mg}$ per $100 \mathrm{ml}$ on another, even though plasma leucine levels reached 22.6 and $26.1 \mathrm{mg}$ per $100 \mathrm{ml}$, respectively. After intravenous administration of leucine, a decrease in blood glucose occurred after plasma levels of leucine had reached 38.2 and $36.9 \mathrm{mg}$ per $100 \mathrm{ml}$, respectively.

Diabetic subjects. Sensitivity to leucine hypoglycemia was produced in three of five mildly diabetic patients by pretreatment with chlorpropamide. The fall in blood glucose levels after leucine administration was much slower (Figure 7) than that seen in chlorpropamide-pretreated healthy subjects (Figures 3 and 4). During the control tests with glycine there were no significant changes in blood glucose levels. Administration of ultralente insulin to lower the fasting blood glucose to levels comparable to those produced by chlorpropamide did not produce sensitivity to leucine hypoglycemia in these three subjects.

Patients with functioning islet-cell adenomas. Oral administration of leucine to one patient with a functioning islet-cell adenoma produced a fall in blood glucose from 55 to $37 \mathrm{mg}$ per $100 \mathrm{ml}$. ILA increased from a fasting level of 485 to 2,600 $\mu \mathrm{U}$ per $\mathrm{ml} 30$ minutes after leucine administration. Changes in blood glucose or ILA levels did not occur during a saline control test. Intravenous administration of leucine to another patient with an insuloma produced a fall in blood glucose levels from 42 to $9 \mathrm{mg}$ per $100 \mathrm{ml}$ in 30 minutes accompanied by an increase of plasma insulin from 20 to $800 \mu \mathrm{U}$ per $\mathrm{ml}$. In a third patient, however, with multiple, small, functioning, islet-cell

\section{A.D., Female, Age 42}

INITIAL F.B.S. $=242 \mathrm{mg} / 100 \mathrm{ml}$.

CHLORPROPAMIDE, $0.75 \mathrm{gm}$. q.d.

(1) LEUCINE TEST ( 8 DAYS)

(2) GLYCINE TEST (II DAYS)

(3) LEUCINE TEST (12 DAYS)

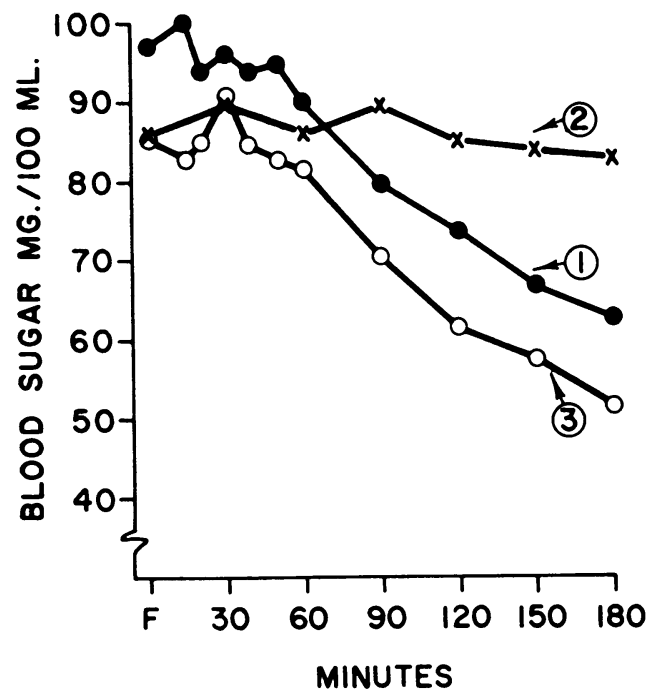

U.L. INSULIN, 35 units q.d.

(1) LEUCINE TEST ( 2 DAYS)

(2) LEUCINE TEST (3 DAYS)

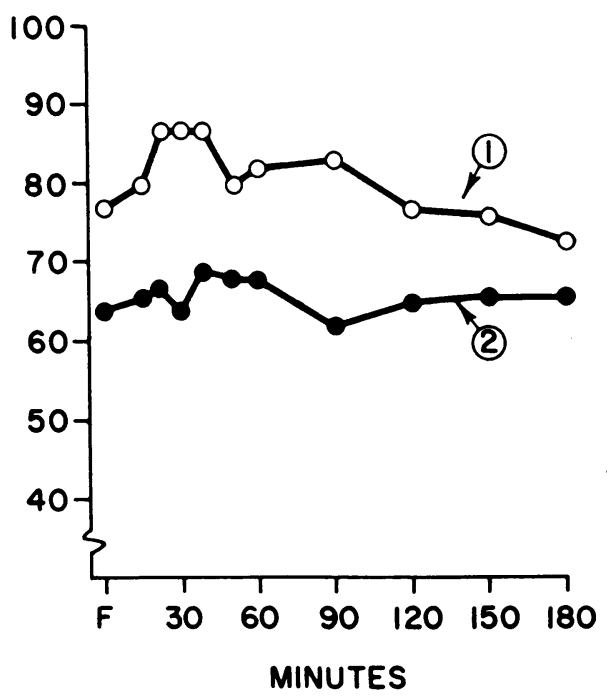

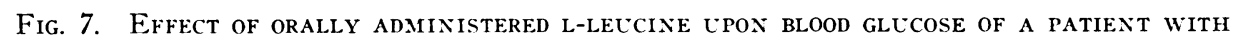
diabetes mellitus pretreated With either chlorpropamide or ultralente insulin. Number of days of pretreatment given in parentheses. 
adenomas, neither oral nor intravenous administration of leucine produced a significant change in blood glucose or ILA levels. The fasting blood glucose levels before the tests were 48 and $42 \mathrm{mg}$ per $100 \mathrm{ml}$. On the other hand, within $30 \mathrm{~min}$ utes after intravenous administration of sodium tolbutamide to this patient on two occasions, there occurred a precipitous fall in blood glucose levels, from 53 and $54 \mathrm{mg}$ per $100 \mathrm{ml}$ to 24 and 16 $\mathrm{mg}$ per $100 \mathrm{ml}$, respectively, accompanied by fourfold increases in ILA levels.

\section{DISCUSSION}

Oral administration of leucine to healthy subjects produces only occasional and small decreases in blood glucose levels. Intravenous administration of leucine to the same subjects produces more consistent, albeit small, decreases in blood glucose levels. This more consistent decrease may be related to the higher levels of plasma leucine after intravenous administration of the amino acid (Table I). In general, however, healthy subjects are much more resistant to the hypoglycemic action of leucine than are some patients with idiopathic hypoglycemia of infancy $(1,4,5)$ and some patients with functioning islet-cell adenomas. In contrast, intravenous administration of sodium tolbutamide to healthy subjects is followed by a consistent and quantitatively greater acute hypoglycemic effect than occurs after intravenous administration of leucine. In twenty subjects, the mean of the maximal decreases in blood glucose levels was $35 \mathrm{mg}$ per $100 \mathrm{ml}$ with a range of 24 to $50 \mathrm{mg}$ per $100 \mathrm{ml}$ (15).

On the other hand, after pretreatment of healthy subjects with sulfonylurea compounds, oral or intravenous administration of leucine produces consistent and large decreases in blood glucose levels similar to those seen in some patients with idiopathic hypoglycemia or functioning islet-cell adenomas. Sulfonylurea compounds have been shown to stimulate the beta cells of the islets of Langerhans and to increase release of endogenous insulin (15-18). The enhanced sensitivity to leucine hypoglycemia after administration of such compounds could be explained on the basis of several possible mechanisms. One might be the potentiation of insulin activity when insulin is present in the circulation in increased amounts. Alternatively, leucine might have an independent hypoglycemic effect only under conditions of increased amounts of insulin. Another important possibility is that of augmented release of insulin by leucine. And finally, more than one of these mechanisms may be activated by leucine.

Potentiation of insulin activity seems most unlikely as a significant factor in experimentallyinduced leucine hypoglycemia in man. Leucine did not magnify the hypoglycemic effect obtained during insulin infusions or during standard insulin tolerance tests. Similar negative results during standard insulin tolerance tests have been reported by Danowski, Bonessi, Balash, and Moses (19). After prolonged administration of ultralente insulin, oral or intravenous administration of leucine produced decreases in blood glucose levels as great, in general, as those observed without pretreatment.

In mildly diabetic subjects in whom the fasting blood glucose level had been reduced to normal by long-acting insulin preparations, leucine did not cause hypoglycemia, whereas it did after chlorpropamide administration. In one of the three patients with functioning islet-cell adenomas, leucine did not produce a hypoglycemic effect even though excessive insulin activity was present.

If enhancement of insulin activity at the hepatic level were an important effect of leucine (or if leucine had a direct inhibitory effect on hepatic glucose output under conditions of increased insulin activity), it might be contended that less insulin is available in the liver after parenteral administration of exogenous insulin than after release of endogenous insulin into the portal system during administration of sulfonylurea compounds. With the amounts of ultralente insulin used, however, and the degree of hypoglycemia attained in many of the insulin experiments, excessive insulin activity must have been present in the liver as well. This was certainly true in the patient with the insuloma, in whom endogenous insulin was released into the portal circulation in amounts sufficient to produce fasting blood glucose levels between 40 and $50 \mathrm{mg}$ per $100 \mathrm{ml}$.

Thus in man the hypoglycemic effect of leucine is not explained on the basis of potentiation of the action of excessive exogenous or endogenous insulin. In dogs, consistent and impressive sensitivity to leucine hypoglycemia has been reported during acute or more prolonged administration of 
insulin (20). At present, these differences in results in men and dogs are not readily explained.

The data suggest that leucine causes hypoglycemia by increasing release of endogenous insulin. Sensitivity to leucine hypoglycemia could be produced consistently after administration of sulfonylureas, compounds that are known to stimulate islet-cell activity. After administration of chlorpropamide, only a modest elevation in plasma levels of leucine had a major hypoglycemic effect. Similar elevation of plasma leucine had little or no effect on blood glucose, with or without pretreatment with ultralente insulin.

Furthermore, after administration of chlorpropamide to healthy subjects and to diabetic patients-sulfonylurea-responsive, sulfonylurea-unresponsive and insulin-dependent, and one pancreatectomized patient-the presence, absence, or type of hypoglycemic response to leucine correlated well with the expected capacity of the pancreatic islets of these subjects to secrete insulin (Figure 3, 4, and 7) (21). Direct evidence that administration of leucine to subjects pretreated with sulfonylurea compounds causes increased release of insulin has been furnished by the finding of significant and consistent increases in peripheral plasma insulin levels as measured by the radioimmunoassay (22), as Figure 4 illustrates. These observations will be described in detail in a subsequent communication. In subjects with idiopathic hypoglycemia of infancy or in patients with functioning islet-cell adenomas, leucine hypoglycemia, when present, has also been associated with increases in levels of plasma insulin (3-7).

The increases in plasma levels of insulin in peripheral venous blood (22) and the decreases in plasma levels of FFA after leucine administration (Table II), suggest that increased release of insulin causes a hypoglycemic effect in part by increasing peripheral carbohydrate utilization. The accentuated decreases reported by Danowski and co-workers (19) in serum levels of phosphate and potassium after combined administration of leucine and tolbutamide to healthy subjects corroborate this conclusion. Since, however, endogenously secreted insulin has a direct effect on the liver (23), a major part of the hypoglycemic effect is undoubtedly due to decreased hepatic glucose output.

Glucagon exerted its normal hyperglycemic ef- fect after administration of leucine or during leucine-induced hypoglycemia. Thus leucine does not seem to interfere with glycogenolysis evoked by glucagon. A normal hyperglycemic effect of glucagon is also seen in some patients with fasting hypoglycemia due to excessive release of insulin from functioning islet-cell adenomas (15).

The data also suggest that leucine-induced and tolbutamide-induced release of insulin occur by different mechanisms. In support of this thesis are the following. 1) In untreated healthy subjects, tolbutamide causes a consistent and pronounced hypoglycemic effect, whereas leucine has an inconsistent and only a small effect. 2) When the same subjects are pretreated with chlorpropamide, leucine has a considerably greater effect in lowering the blood glucose level than does intravenous tolbutamide (Table IV). 3) In one patient with a functioning islet-cell adenoma, orally or intravenously administered leucine had no effect on blood glucose levels [a hypoglycemic effect of leucine was found in only four of seven patients with functioning islet-cell tumors (24)]. On the other hand, intravenously administered tolbutamide caused profound hypoglycemia (15). 4) In some patients with idiopathic hypoglycemia of infancy, leucine causes severe hypoglycemia, whereas tolbutamide is associated with a normal hypoglycemic effect $(4,15,25)$.

In the course of these experiments, it became clear that although the effects of orally administered leucine upon blood glucose of healthy subjects were small and inconsistent, a leucine-induced hypoglycemic effect nevertheless occurred more frequently than expected from previous reports $(1,2,4)$. The more consistent hypoglycemic effect after intravenous administration of leucine to healthy subjects appears to make these findings more significant. "A small depression" of blood glucose levels after the intravenous administration of leucine to normal infants and children has been reported previously by $\mathrm{Di}$ George (24). These data suggest that leucine can induce release of additional insulin in many normal people, and also that a mild hypoglycemic response to leucine in the parent of a patient with idiopathic hypoglycemia may be a normal response and may not necessarily indicate familial sensitivity to leucine hypoglycemia.

The modest hypoglycemic effect obtained by 
administration of leucine to some subjects pretreated with ultralente insulin may also be due to increased release of insulin. The data suggest that under these circumstances, higher blood levels of leucine were required to produce a hypoglycemic effect than without pretreatment. It could be that the depressing effect of exogenous insulin on normal islets of Langerhans decreased their responsiveness to leucine.

Further study of the phenomena discussed should provide more insight regarding the mechanism by which leucine induces insulin release and should increase our understanding of the normal interrelationship between amino acid metabolism, insulin release and activity, and carbohydrate metabolism. The ease with which experimental sensitivity to leucine hypoglycemia can be produced in healthy subjects by administration of the sulfonylurea compounds greatly facilitates an approach to such investigations.

\section{SUMMARY}

L-Leucine was administered orally or intravenously to healthy subjects before and during treatment with either sulfonylurea compounds or ultralente insulin, as well as during infusions with insulin. Leucine tests were also performed on patients with functioning islet-cell adenomas and diabetic patients treated either with chlorpropamide or insulin.

In healthy subjects, the effect of leucine upon blood glucose levels was small and inconsistent, but after pretreatment with sulfonylurea compounds, leucine produced consistent and large decreases in blood glucose. Leucine did not magnify the hypoglycemic effect obtained during infusions of insulin. After prolonged administration of ultralente insulin, administration of leucine produced decreases in blood glucose levels as great, in general, as those observed without pretreatment. In some diabetic patients, leucine hypoglycemia could be induced during administration of chlorpropamide but not insulin. Orally or intravenously administered leucine had no effect upon blood glucose of one of three patients with functioning islet-cell adenomas, whereas intravenously administered tolbutamide had a severe hypoglycemic effect.

It is concluded that: 1) sensitivity to leucine hypoglycemia can be induced consistently in healthy subjects after administration of sulfonylurea compounds, 2) release of insulin is the primary mechanism of action by which leucine causes hypoglycemia in man, 3) leucine induces insulin release by a mechanism different from that produced by tolbutamide, 4) potentiation of insulin activity cannot be demonstrated to play a role in the production of leucine-induced hypoglycemia in man, and 5) the ability of sulfonylureas to induce sensitivity to leucine hypoglycemia in normal persons should simplify future investigations of the phenomenon of leucine-sensitivity.

\section{REFERENCES}

1. Cochrane, W. A., Payne, W. W., Simpkiss, M. J., and Woolf, L. I. Familial hypoglycemia precipitated by amino acids. J. clin. Invest. 1956, 35, 411.

2. Flanagan, G. C., Schwartz, T. B., and Ryan, W. G. Studies on patients with islet-cell tumor, including the phenomenon of leucine-induced accentuation of hypoglycemia. J. clin. Endocr. 1961, 21, 401.

3. Yalow, R. S., and Berson, S. A. Immunoassay of endogenous plasma insulin in man. J. clin. Invest. $1960,39,1157$.

4. Grumbach, M. M., and Kaplan, S. L. Amino acid and alpha-keto acid-induced hyperinsulinism in the leucine-sensitive type of infantile and childhood hypoglycemia. J. Pediat. 1960, 57, 346.

5. Mabry, C. C., DiGeorge, A. M., and Auerbach, V. H. Leucine-induced hypoglycemia. II. Studies concerning other amino acids and leucine metabolites. J. Pediat. 1960, 57, 539.

6. Weisenfeld, S., and Goldner, M. G. Hyperinsulinemia in L-leucine-sensitive hypoglycemia in an adult. Amer. J. Med. 1961, 31, 659.

7. Marks, J. F., and Klein, R. Effect of leucine on plasma insulin concentration in a girl with a pancreatic adenoma. J. clin. Endocr. 1961, 21, 1498

8. Fajans, S. S., Power, L., Gwinup, G. W., Knopf, R. F., and Conn, J. W. Studies on the mechanism of leucine hypoglycemia (abstract). J. Lab. clin. Med. 1960, 56, 810.

9. Fajans, S. S., Knopf, R. F., Power, L., and Conn, J. W. Experimentally-induced sensitivity to leucine hypoglycemia in healthy people and in diabetic subjects (abstract). Program, ann. Meeting Amer. Diab. Ass., New York City, June 24-25, 1961, p. 15.

10. Nelson, N. A photometric adaptation of the Somogyi method for the determination of glucose. J. biol. Chem. 1944, 153, 375.

11. Berry, H. K. Paper chromatographic method for estimation of phenylalanine. Proc. Soc. exp. biol. (N. Y.) $1957,95,71$. 
12. Dole, V. P. A relation between non-esterified fatty acids in plasma and the metabolism of glucose. J. clin. Invest. 1956, 35, 150.

13. Renold, A. E., Martin, D. B., Dagenais, Y. M., Steinke, J., Nickerson, R. J., and Sheps, M. C. Measurement of small quantities of insulin-like activity using rat adipose tissue. I. A proposed procedure. J. clin. Invest. 1960, 39, 1487.

14. Knauff, R. E., Fajans, S. S., Ramirez, E., and Conn, J. W. Metabolic studies of chlorpropamide in normal men and in diabetic subjects. Ann. N. Y. Acad. Sci. 1959, 74, 603.

15. Fajans, S. S., Schneider, J. M., Schteingart, D. E., and Conn, J. W. The diagnostic value of sodium tolbutamide in hypoglycemic states. J. clin. Endocr. 1961, 21, 371.

16. Loubatières, A. The mechanism of action of the hypoglycemic sulfonamides: a concept based on investigations in animals and human beings. Ann. N. Y. Acad. Sci. 1957, 71, 192.

17. Yalow, R. S., Black, H., Villazon, M., and Berson, S. A. Comparison of plasma insulin levels following administration of tolbutamide and glucose. Diabetes 1960, 9, 356.

18. Seltzer, H. S. Quantitative effects of glucose, sulfonylureas, salicylate, and indole-3-acetic acid on the secretion of insulin activity into pancreatic venous blood. J. clin. Invest. 1962, 41, 289.
19. Danowski, T. S., Bonessi, J. V., Balash, W. R., and Moses, C. Leucine prolongation of tolbutamideinduced hypoglycemia. Metabolism 1962, 11, 556.

20. Reaven, G., and Lucas, C. The use of insulin in the production of L-leucine-induced hypoglycemia in normal dogs. J. clin. Invest. 1962, 41, 654.

21. Gwinup, G. Leucine hypoglycemia in states of reduced islet function. Diabetes 1962, 11, 397.

22. Floyd, J. C., Jr., Fajans, S. S., Knopf, R. E., and Conn, J. W. Blood insulin levels during experimentally-induced leucine hypoglycemia (abstract). Program, 44th Meeting Endocr. Soc., Chicago, June 21-23, 1962, p. 34.

23. Madison, L. L., Combes, B., Adams, R., and Strickland, W. The physiological significance of the secretion of endogenous insulin into the portal circulation. III. Evidence for a direct immediate effect of insulin on the balance of glucose across the liver. J. clin. Invest. 1960, 39, 507.

24. Di George, A. M., and Auerbach, V. H. Leucineinduced hypoglycemia. A review and speculations. Amer. J. med. Sci. 1960, 240, 792.

25. Kaplan, S. L., Schotland, M. G., and Grumbach, M. M. Response to tolbutamide in the leucinesensitive type of infantile and childhood hypoglycemia (abstract). Amer. J. Dis. Child. 1961, 102, 620. 